\title{
The Effect of Marketing Strategy and Service Quality on Customer Satisfaction and Its Impact on Customer Loyalty of BJB Bank in Bekasi
}

\author{
Waseso Segoro ${ }^{1, *}$ Lela Elvira ${ }^{2}$
}

\author{
${ }^{1}$ Universitas Gunadarma \\ ${ }^{2}$ Universitas Gunadarma \\ *Corresponding author.Email: waseso@staff.gunadarma.ac.id
}

\begin{abstract}
This research is shown to test the influence of marketing strategy, service quality, and customer satisfaction on customer loyalty for his desire to add more savings in tandamata. The data used in this study comes from the questionnaire that has been distributed to customers who have made the product savings tandamata futures. The sample in this study is the customer, with a sample number of 135 respondents. This research method uses Structural Equation Modeling (SEM) with confirmatory analysis, with AMOS software used to analyze data. The analysis results by software processing show a positive influence of marketing strategy and service quality on customer satisfaction and then customer satisfaction with customer loyalty and cannot influence the marketing strategy and service quality on customer loyalty.
\end{abstract}

Keywords: Strategy Marketing, Service Quality, Customer Satisfaction, Customer Loyalty, And Structural Equation Modeling.

\section{INTRODUCTION}

The phenomenon that occurs in BJB bank is that the majority of BJB bank customers are civil servants (PNS). Besides, in the banking world today, the number of banking customer service or marketing personnel have poor ethics in selling banking products, where they often do mass selling. There is a lot of customer service or marketing that is not well understood or lacks in mastering the product knowledge that it sells, and there is even marketing that intentionally makes the products it sells as attractive as possible, but it does not exist in marketing tools. Not only that, but customers also find it difficult to get valid information because the information from the call center is sometimes incorrect. Hence, when customers come directly to the bank, they get different information again. For example, customers do not feel well-served if they contact the call center. Even customers have to wait too long. Many BJB bank customers are reluctant to put their funds back and feel uncomfortable and secure by having savings from this phenomenon. The customers feel being cheated by the BJB bank, which negatively impacts the bank bjb's image in business continuity in the future. Table 1 and Fig. 1. show product sales form 2013 to 2017.
Table 1. Product sales form 2013 to 2017

\begin{tabular}{|c|c|c|c|c|c|}
\hline $\begin{array}{l}\mathbf{N} \\
\mathbf{0}\end{array}$ & $\begin{array}{l}\text { Ye } \\
\text { ar }\end{array}$ & $\begin{array}{l}\text { Tanda } \\
\text { mata } \\
\text { Savings } \\
\text { Product } \\
\text { s With } \\
\text { Govern } \\
\text { ment } \\
\text { Progra } \\
\text { ms }\end{array}$ & $\begin{array}{l}\text { Tanda } \\
\text { mata } \\
\text { Saving } \\
\text { S } \\
\text { Produc } \\
\text { ts With } \\
\text { Term }\end{array}$ & $\begin{array}{l}\text { Mark } \\
\text { et } \\
\text { Savin } \\
\text { gs } \\
\text { Prod } \\
\text { ucts }\end{array}$ & $\begin{array}{l}\text { Percen } \\
\text { tage }\end{array}$ \\
\hline 1 & $\begin{array}{l}20 \\
13\end{array}$ & 75.281 & 315 & 2.382 & $13,2 \%$ \\
\hline 2 & $\begin{array}{l}20 \\
14\end{array}$ & 72.132 & 252 & 2.166 & $11,6 \%$ \\
\hline 3 & $\begin{array}{l}20 \\
15 \\
\end{array}$ & 70.837 & 202 & 2.008 & $10 \%$ \\
\hline 4 & $\begin{array}{l}20 \\
16 \\
\end{array}$ & 68.490 & 162 & 1.874 & $8,6 \%$ \\
\hline 5 & $\begin{array}{l}20 \\
17\end{array}$ & 64.320 & 135 & 1.656 & $8,1 \%$ \\
\hline
\end{tabular}




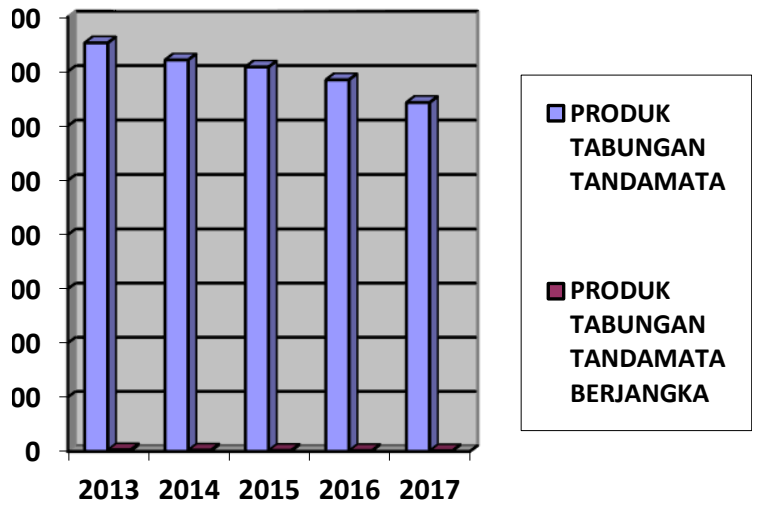

Figure 1 Total sales

Based on the Fig 1, the total sales of timed products in 2013 were 315 customers. Nevertheless, the decline in product sales continued from 2014 to 2017, with 135 customers. This is a particular interest for researchers to study the factors influencing people's interest in opening time-saving savings accounts.

\subsection{Marketing}

Marketing is a business function that identifies unmet needs and desires, defines and regulates the size, determines which target market is the best that can be served, determines products/services and programs suitable to serve the market [1].

\subsection{Service quality}

Quality is the totality of features and characteristics of a product or service that bear on its ability to satisfy stated or implied needs [2].

\subsection{Customer satisfaction}

Customer satisfaction is an emotional reaction of postpurchase customers: anger, dissatisfaction, irritation, neutrality, excitement, or pleasure [3].

\subsection{Customer loyalty}

Customer loyalty is the customer's decision to voluntarily continue to subscribe to certain companies for a long time [4].

\subsection{Research framework}

\section{Hypothesis}

$\mathrm{H1}$ : There is an influence of the marketing strategy on customer satisfaction to add new products to the term savings account BJB.
$\mathrm{H} 2$ : There is an influence of service quality on customer satisfaction to add new products to the term savings account BJB.

H3: There is an influence of the marketing strategy on customer loyalty to add a savings account for BJB futures.

$\mathrm{H} 4$ : There is an influence of service quality on customer loyalty to add BJB savings products.

H5: There is an influence of customer satisfaction on customer loyalty so that there is a sense of desire for customers to add savings products to the BJB futures.

\section{METHODS}

\subsection{Approach, population, and sample}

This study adapted multiple linear regression analysis. The population is the customer who opened a time-saving savings account in 2017 at the Bekasi BJB bank, Indonesia. The sample is determined by the Slovin technique, which produces 135 respondents.

\subsection{Data collection}

Data is primary and collected through the distribution of questionnaires containing a list of questions to be answered by the respondents.

\subsection{Data analysis}

Data were analyzed using the Structural Equation Modelling (SEM), supported by AMOS 22 program.

\section{RESULTS AND DISCUSSION}

\subsection{Full model confirmatory factor analysis (CFA) Test}

After conducting a confirmatory test on the variables of marketing strategy, service quality, customer satisfaction, and customer loyalty, it is found that all variable construct indicators have a probability value $\mathrm{p}<$ 0.05 and meet the convergent validity value. So it can be concluded that the data in the full model diagram is valid. The results of the Full Model Confirmatory Factor Analysis (CFA). Fig 2 show the full model of structural equation. 


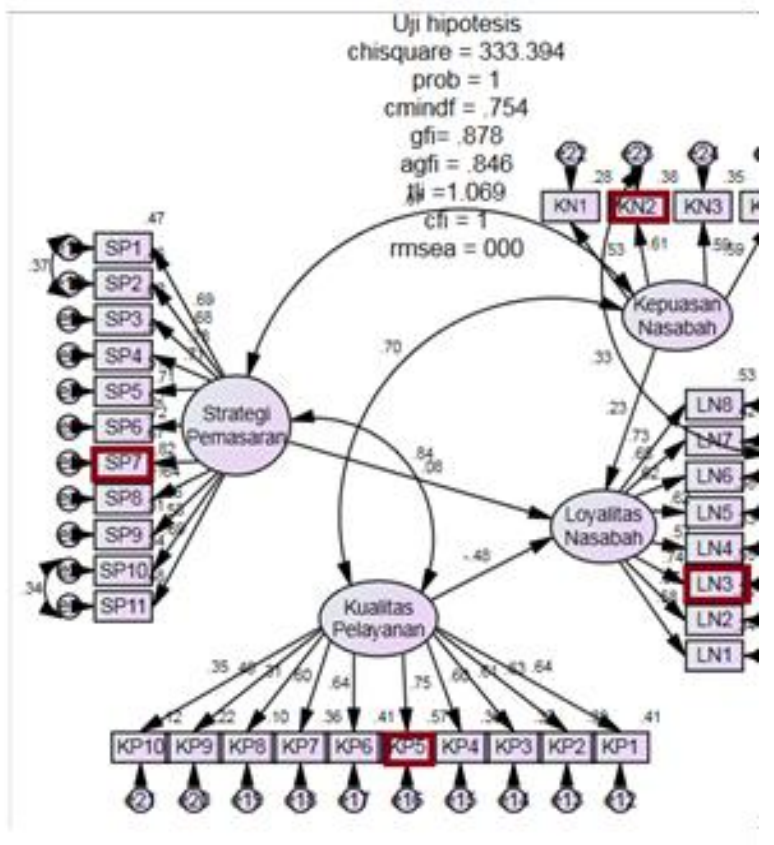

Figure 2 The full model of structural equations

\subsection{Goodness of fit test}

Chi-square (X2) in this study amounted to 333,394 with a probability index of 0,000 . The RMSEA results have a value of less than 0.08 , which is equal to 0.061 , and CMIN / DF gets a value of less than 2, which is equal to 1.496 , which means the two measurement indices are a good fit. Other indices such as GFI, AGFI, TLI, and CFI show marginal levels of fit. Table 2 show the result of fit test, and Table 3 show the result of research.

Table 2. Summary of research result

\begin{tabular}{|l|l|l|l|l|}
\hline $\begin{array}{l}\text { No } \\
\cdot\end{array}$ & $\begin{array}{l}\text { The } \\
\text { goodness } \\
\text { of Fit } \\
\text { Index }\end{array}$ & $\begin{array}{l}\text { Cutt-of } \\
\text { Value }\end{array}$ & Result & $\begin{array}{l}\text { Model } \\
\text { Evaluatio } \\
\text { n }\end{array}$ \\
\hline 1. & $\begin{array}{l}\text { X2-Chi- } \\
\text { Square }\end{array}$ & $\begin{array}{l}\text { Expecte } \\
\text { d small }\end{array}$ & $\begin{array}{l}728.42 \\
1\end{array}$ & $\begin{array}{l}\text { Marjinal } \\
\text { Fit }\end{array}$ \\
\hline 2. & $\begin{array}{l}\text { Significa } \\
\text { nt } \\
\text { Probabilit } \\
\text { y }\end{array}$ & $\leq 0.05$ & 0.000 & Not Fit \\
\hline 3. & RMSEA & $\leq 0.08$ & 0.061 & Good Fit \\
\hline 4. & GFI & $\geq 0.90$ & 0.755 & $\begin{array}{l}\text { Marjinal } \\
\text { Fit }\end{array}$ \\
\hline 5. & AGFI & $\geq 0.90$ & 0.718 & $\begin{array}{l}\text { Marjinal } \\
\text { Fit }\end{array}$ \\
\hline 6. & $\begin{array}{l}\text { CMIN/D } \\
\text { F }\end{array}$ & $\leq 2.00$ & 1.496 & Good Fit \\
\hline 7. & TLI & $\geq 0.95$ & 0.861 & $\begin{array}{l}\text { Marjinal } \\
\text { Fit }\end{array}$ \\
\hline 8. & CFI & $\geq 0.95$ & 0.872 & $\begin{array}{l}\text { Marjinal } \\
\text { Fit }\end{array}$ \\
\hline
\end{tabular}

Table 3. Summary of research result

\begin{tabular}{|c|c|c|c|c|}
\hline Hypothesis & Variables & $\begin{array}{l}\text { Data } \\
\text { Analysis }\end{array}$ & Result & Meaning \\
\hline H1 & $\begin{array}{l}\text { Marketing } \\
\text { Strategy } \rightarrow \\
\text { Customer } \\
\text { Satisfaction }\end{array}$ & $\begin{array}{l}\text { C.R }= \\
2,819> \\
1.96 \\
\text { P-value = } \\
0.005< \\
0.05\end{array}$ & Influential & $\begin{array}{l}\text { Influential customer satisfaction if applying } \\
\text { a unique marketing strategy is different } \\
\text { from competing banks because customers } \\
\text { can see marketing strategies such as } \\
\text { advertisements and attractive promos. }\end{array}$ \\
\hline $\mathrm{H} 2$ & $\begin{array}{l}\text { Service Quality } \\
\rightarrow \text { Customer } \\
\text { Satisfaction }\end{array}$ & $\begin{array}{l}\text { C.R }= \\
3.934> \\
1.96 \\
\text { P-value = } \\
0.000< \\
0.05\end{array}$ & Influential & $\begin{array}{l}\text { Influential customer satisfaction is seen } \\
\text { from the quality of service available. } \\
\text { Because customers feel comfortable with } \\
\text { excellent service, customers will feel their } \\
\text { satisfaction from the impact of good service } \\
\text { quality. }\end{array}$ \\
\hline H3 & $\begin{array}{l}\text { Marketing } \\
\text { Strategy } \\
\rightarrow \text { Customer } \\
\text { Loyalty }\end{array}$ & $\begin{array}{l}\text { C.R }= \\
1.367< \\
1.96 \\
\text { P-value }= \\
0.172> \\
0.05\end{array}$ & $\begin{array}{l}\text { No } \\
\text { Influential }\end{array}$ & $\begin{array}{l}\text { Customer loyalty does not affect the } \\
\text { marketing strategy because customer loyalty } \\
\text { starts from customer satisfaction first. }\end{array}$ \\
\hline
\end{tabular}




\begin{tabular}{|l|l|l|l|l|}
\hline H4 & Service Quality & C.R $=$ & No & Customer loyalty does not affect service \\
& $\rightarrow$ Customer & $1.895<$ & Influential & quality because customer loyalty starts from \\
& Loyalty & 1.96 & & customer satisfaction first. \\
& & P-value & & \\
& & $0.58>$ & & \\
& & 0.05 & & \\
\hline H5 & Customer & C.R $=$ & Influential & Customer loyalty affects customer \\
& Satisfaction $\rightarrow$ & $5.975>$ & & satisfaction because satisfaction and \\
& Customer & 1.96 & & customer confidence level becomes high, so \\
& Loyalty & P-value & & loyalty is also higher. \\
& & $0.000<$ & & \\
& & 0.05 & & \\
\hline
\end{tabular}

Based on the table above, the results of this study prove the hypothesis proposed is correct. Marketing strategies affect customer satisfaction. Service quality affects customer satisfaction, customer satisfaction affects customer loyalty, while marketing strategies and service quality do not affect customer loyalty.

\section{CONCLUSIONS}

\subsection{Conclusion}

Based on the data analysis, hypotheses tests, and discussion, it can be ascertained that:

1) Research shows that marketing strategies have a positive and significant influence on customer satisfaction. The effect is based on the Critical Ratio (C.R) value of 2.819 and the P-value of $0.005<0.05$

2) Research shows that service quality has a positive and significant influence on customer satisfaction. The influence is based on the Critical Ratio (C.R) value of 3.934 , and the P-value is $0.000<0.05$.

3) Research shows that marketing strategies have no significant effect on customer loyalty. The effect is based on the Critical Ratio (C.R) value of 1.367 and the P-value of $0.172>0.05$.

4) Research shows that service quality has no significant effect on customer loyalty. The effect is based on the Critical Ratio (C.R) value of 1.895 and the $\mathrm{P}$-value of $0.58>0.05$.

5) Research shows that customer satisfaction has a positive and significant influence on customer loyalty. The influence is based on the Critical Ratio (C.R) value of 5.975 and the P-value of $0.000<0.05$.

\subsection{Implications}

Based on the results, the researchers suggest that:
1) Creating customer satisfaction through marketing strategies, companies need to pay attention to several aspects based on market education, promotion, and communication indicators. Companies can expand market share by presenting products with different characteristics and products tailored to market conditions. Implementing a good marketing strategy is expected to create better performance advantages to increase competitive advantage in their business and achieve the desired target. Influential customer satisfaction if applying a unique marketing strategy is different from competing banks because customers can see marketing strategies such as advertisements and attractive promos.

2) Creating customer satisfaction through service quality, companies need to pay attention to several aspects based on tangible, empathy, reliability, responsiveness, and insurance indicators. Companies need to be a motivator for human resources to continue to grow. In addition, in terms of improving creativity and conducting training, employees will have more extensive knowledge and insights, with more qualified human resources, which will undoubtedly improve service quality and create customer satisfaction. By implementing creativity, it is expected to increase the superiority of more productive human resource operational expertise so that it will have an impact on improving service quality and customer satisfaction.

3) Creating customer loyalty through marketing strategies, companies need to pay attention to several aspects based on customer loyalty indicators, namely, repeat purchase, pay more, advocate, and retention. Companies need to pay attention to customer orientation, competitor orientation, and coordination between functions. In addition, in the marketing strategy indicators, the company must also pay attention to customer satisfaction so that it has an impact on customer loyalty, this will also have an impact on increasing the opportunity target for competitive advantage, and coordination between functions can be done by increasing customer information distribution in each company. By 
implementing an adequate and appropriate marketing strategy at the same time can make customers loyal.

4) Creating customer loyalty through service quality. Customer loyalty does not affect service quality because customer loyalty starts from customer satisfaction. The company needs to pay attention to several aspects based on service quality indicators (tangible, empathy, reliability, responsiveness, and company insurance). The company also needs to pay attention to superior skills, superior resources, and performance excellence. Companies can improve the expertise of human resources and performance excellence by providing intense training, and companies can also improve performance excellence by paying attention to design values so that the company has a new and unique product design. Enhancing expert human resources and improving performance excellence makes customers become unsaturated with existing products and will impact customers will be loyal.

5) Creating customer loyalty through customer satisfaction. Customer loyalty affects customer satisfaction because customer loyalty starts from customer satisfaction first. The company needs to pay attention to several aspects based on customer satisfaction indicators, namely overall customer satisfaction. Companies need to pay attention to the creativity and innovation of their human resources. Companies need to be a motivator for all human resources in order to continue to grow. In creating customer loyalty through customer satisfaction, customer confidence level's satisfaction becomes high, so the value of loyalty is also higher. Applying creativity and innovation in human resources can improve service quality. This is supported by the availability of quality human resources. These conditions will have an impact on customer satisfaction so that customers will be loyal.

Based on the unidimensionality testing of each construct with Confirmatory Factor Analysis (CFA), it can be concluded that the SP7 construct variable is valid with the immense value of 0.831 compared to the other construct variables at a significant level of 0.05 . Therefore, a good marketing strategy is vital for the company's business progress to achieve the desired target.

\section{REFERENCES}

[1] P. Kotler, and G. Armstrong, Principle of Marketing. 15 ${ }^{\text {th }}$ Ed. Prentice Hall. 2013.

[2] P. Kotler, and K.L. Keller, Marketing management. $2^{\text {nd }}$ Ed. Prentice Hall. 2013.
[3] C. Lovelock, J. Wirtz, and J. Mussry, Pemasaran jasa manusia, teknologi, strategi: perspektif Indonesia, 7Ed. Jakarta: Erlangga. 2010.

[4] C. Lovelock, P. Patterson, and J. Wirtz, Services marketing: an Asia-Pasific and Australian perspective. Sixth Ed. Australia: Pearson. 2015 